FEDERAL RESERVE BANK OF MINNEAPOLIS

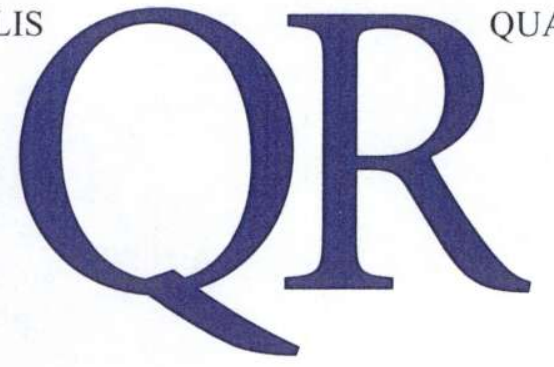

QUARTERLY REVIEW

July 2008

If Exchange Rates Are Random Walks, Then Almost Everything We Say about Monetary Policy Is Wrong

Fernando Alvarez

Andrew Atkeson

Patrick J. Kehoe

Back to the Future with Keynes

Lee E. Ohanian 


\section{FEDERAL RESERVE BANK OF MINNEAPOLIS Quarterly Review Vol. 32, No.1}

ISSN 0271-5287

This publication primarily presents economic research aimed at improving policymaking by the Federal Reserve System and other governmental authorities.

Any views expressed herein are those of the authors and not necessarily those of the Federal Reserve Bank of Minneapolis or the Federal Reserve System.

EDITOR: Arthur J. Rolnick

ASSOCIATE EDITORS: Patrick J. Kehoe, Warren E. Weber

ARTICLE EDITOR: Joan M. Gieseke

PRODUCTION EDITOR: Joan M. Gieseke

DESIGNER: Phil Swenson

TYPESETTING: Mary E. Anomalay

CIRCULATION ASSISTANTS: Mary E. Anomalay, Barbara Drucker
The Quarterly Review is published by the Research Department of the Federal Reserve Bank of Minneapolis. Subscriptions are available free of charge. This has become an occasional publication, which is published once or twice a year. The publication, however, continues to be known as the Quarterly Review for citation purposes.

Quarterly Review articles that are reprints or revisions of papers published elsewhere may not be reprinted without the written permission of the original publisher. All other Quarterly Review articles may be reprinted without charge. If you reprint an article, please fully credit the source-the Minneapolis Federal Reserve Bank as well as the Quarterly Review-and include with the reprint a version of the standard Federal Reserve disclaimer (italicized left). Also, please send one copy of any publication that includes a reprint to the Minneapolis Fed Research Department.

Electronic files of Quarterly Review articles are available through the Minneapolis Fed's home page on the World Wide Web: http://www.minneapolisfed.org.

Comments and questions about the Quarterly Review may be sent to:

Quarterly Review

Research Department

Federal Reserve Bank of Minneapolis

P. O. Box 291

Minneapolis, MN 55480-0291

(Phone 612-204-6455/Fax 612-204-5515)

Subscription requests may be sent to the circulation assistant at mea@res.mpls.frb.fed.us. 


\title{
Back to the Future with Keynes*
}

\author{
Lee E. Ohanian \\ Professor of Economics \\ University of California, Los Angeles \\ and Consultant \\ Federal Reserve Bank of Minneapolis
}

In the early stages of the Great Depression, John Maynard Keynes took time out from his role as a policy adviser, research economist, and economic journalist to write "Economic Possibilities for our Grandchildren," an essay presenting his forecasts for the world economy of the 21 st century. Published in 1930, "Economic Possibilities" reveals a fascinating and very different portrait of Keynes. The essay shows that Keynes had an understanding of modern economic growth that was at least 25 years ahead of his time. His views about long-run growth are very similar to today's frontier growth theory, more so than his much better known and much more influential views about business cycles. Keynes's qualitative and quantitative predictions of the continuing success of the leading economies were remarkably accurate. After making these extraordinarily accurate 100-year predictions, Keynes freely moves away from economics to try on the much broader hat of a wideranging social scientist and social critic. But here, Keynes's assessments are wide off the mark, reflecting his idiosyncratic views about human nature and the counterfactual view that the income elasticity of leisure was much higher than that of consumption in the long run.

\section{Keynes on Growth: Way Ahead of His Time}

The modern theory of economic growth-Solow (1956), Swan (1956), Cass (1965), Koopmans (1965), Lucas
(1988), and Romer (1990) — provides the foundation for long-run (steady-state) growth driven by technological change and capital accumulation, and provides the standard competitive decentralization for growth economies. Given a constant rate of technological progress, a plausibly restricted one-sector growth model can establish a unique long-run growth path with monotonic convergence to that path for any value of the capital stock. The breakthrough development of modern growth theory, combined with over 200 years of roughly average per capita growth, provides modern economists with an advanced understanding of long-run economic behavior and the ability to make reasonably accurate predictions. For example, Leamer (2004) shows that real GDP over nearly the last 40 years has never been more than 3 percent above or below its long-run trend of about 3 percent growth. But would any economist today, even with the benefit of training in frontier growth theory, try to make serious economic projections 100 years out? Very unlikely, but Keynes did, and did so remarkably well - in all honesty, much too well - given the available theory and the existing economic conditions when he was writing.

*Reprinted from Revisiting Keynes: Economic Possibilities for Our Grandchildren, edited by Lorenzo Pecchi and Gustavo Piga, to be published by the MIT Press in the fall of 2008. 
Keynes, as well as other leading economists of the early 20th century, did not have sufficient theory nor a sufficient empirical record to gauge long-run economic behavior the way modern economists can. Growth theory - as we know it today - did not exist in the 1930s. There was little in the way of theory that would lead an economist of that era to confidently predict a stable steady-state growth path in which output remains close to its long-run trend. The Harrod-Domar model that was developed in the 1930s predicted that market economies were unstable, with chronically high unemployment, and that steady states were knife-edge propositions.

There was also little to guide an economist to confidently predict long-run changes from an empirical perspective. At the time "Economic Possibilities" was written, the United Kingdom was entering its second decade of severe depression. Real GDP per person in 1930 relative to a 1.4 percent average trend was more than 20 percent below its 1913 level, and had been close to 20 percent below trend during the entire previous decade. Moreover, hours worked were 27 percent below its historical average throughout the 1920s and 1930s (see Cole and Ohanian 2002). Keynes somehow remained optimistic after more than a decade of abysmal economic performance in his own country, and with the start of the Great Depression around the rest of the world:

It is common to hear people say that the epoch of enormous economic progress ... is over; that the rapid improvement in the standard of life is now going to slow down. . . . I believe that this is a wildly mistaken interpretation of what is happening. ... [T] he economic problem may be solved ... within a hundred years. . . [T] he standard of life in progressive countries one hundred years hence will be between four and eight times as high as it is to-day.

The "economic problem," as Keynes called it, has certainly been solved for the majority of households in the "progressive countries" over the last 75 years, as Keynes's forecast that per capita income would advance by a factor of four to eight between 1930 and 2030 (which is an eerily accurate average growth rate of between 1.4 to 2.1 percent per capita across the industrialized countries) has indeed been realized. Moreover, rapid growth over the last 50 years has made many East Asian countries rich, and by 2030 , which is the end of Keynes's 100-year horizon, there is enormous potential for much of the world's remaining population to achieve a reasonable degree of economic success. China and India, which together account for close to 40 percent of the world's population, have clearly entered the era of modern economic growth, and may double their per capita income levels by 2030 .

Perhaps the only regions during the lifetimes of Keynes's "grandchildren" to remain in poverty will be Africa and the Middle East, and certainly no one in 1930 could have foreseen the enormous development impediments that these two regions face. Keynes's long-run forecasts were remarkable well beyond any reasonable expectation for success in this venture.

What factors led Keynes to make such "startling" and accurate projections? Perhaps the most important reason is that Keynes had all the makings of a superb growth theorist. "Economic Possibilities" reveals that Keynes had a sophisticated understanding of the key ingredients that would form the foundations of the modern theory of economic growth, which would not be written for 30 years: technological advances, capital accumulation, low population growth. Keynes combined these ingredients with a strong expectation of the robustness of the steady-state growth path, rather than the knifeedge nature of the growth path of the Harrod-Domar model that dominated growth until Solow's 1956 paper. Keynes's discussion of the transformation of the leading economies from the Malthusian era-in which there was virtually no per capita income growth - to the era of sustained economic growth could appear in a modern growth text or journal article:

From the sixteenth century, with a cumulative crescendo after the eighteenth, the great age of science and technical inventions began. . . . What is the result? In spite of an enormous growth in the population of the world ... the average standard of life in Europe and the United States has been raised, I think, about fourfold. . . . [I]n our own lifetimes ... we may be able to perform all the operations of agriculture, mining, and manufacture with a quarter of the human effort to which we have been accustomed.

Keynes's views on long-run growth, featuring the role of labor-saving technological change and capital accumulation, are squarely in line with modern neoclassical growth theory. His insights into the process of growth are truly striking.

But there is a bit-or more than a bit —of luck contributing to Keynes's successful predictions, as he perceived the depressions of the 1920s and 1930s as purely transitory episodes that were related to post-World War I adjustments. In contrast, recent studies of depressionsincluding the U.K. depression that began in 1921 and 
that would continue until after World War II-show that these long-run episodes were the consequence of poorly designed government policies that substantially reduced steady-state hours and/or productivity. From this perspective, the depressions of the 1920s and 1930s should have led Keynes to have important reservations about the future long-run performance of the industrial economies. Keynes, however, dismissed the impact of these policies, and clearly considered the U.K. depression and the Great Depression as a transitory phenomenon that was unrelated to labor policies:

We are suffering ... from the growing-pains of over-rapid changes, from the painfulness of readjustment between one economic period and another. ... [T] he banking and monetary system of the world has been preventing the rate of interest from falling as fast as equilibrium requires.

Of course, Keynes did not have the benefit of modern theory to guide his assessment. But other leading economists of the early 20th century clearly understood the contractionary implications of the policies adopted at that time. Pigou (1927) described how the United Kingdom's protracted depression was significantly affected by government policies:

$[\mathrm{P}]$ artly through direct State action, and partly through the added strength given to workpeople's organisations engaged in wage bargaining by the development of unemployment insurance, wage-rates have, over a wide area, been set at a level which is too high ... and that the very large percentage of unemployment which has prevailed during the whole of the last six years is due in considerable measure to this new factor.

More generally, Keynes held the view that government policies that significantly changed the incentives to work and save did not have any significant negative effects. In the 1940s he argued that the United Kingdom should significantly increase the taxation of capital income and adopt a capital levy, and his views considerably influenced U.K. tax policies through the 1970s. During the early stages of World War II, Sir John Hicks debated Keynes about the effect of high capital income tax rates. Hicks argued that high tax rates would reduce the rate of capital accumulation and growth, to which Keynes replied, "My Dear Hicks, I scarcely imagine that individuals are as actuarially-minded as you presume they are." The view that capital accumulation was insensitive to taxes led Keynes to conclude that capital income should be taxed at nearly 100 percent during the war, and that a permanent capital levy should be adopted following the war (see Cooley and Ohanian 1997).

Keynes's failure to understand the distorting effects of government policies, and his view that economic depressions were temporary bumps on the road, were central for his very optimistic and very accurate forecast of continuing long-run economic growth. Keynes was unbelievably accurate, but some of this accuracy is for the wrong reasons. The advanced economies were ultimately able to grow because the worst government policies of the 1920s and 1930s were reformed or eliminated. The U.K. unemployment benefits system, which initially provided very high benefit levels indefinitely for employment tenure of as little as one day, was reformed considerably, and the capital tax rate of nearly 100 percent that was adopted in the 1940s declined to a level comparable to that in the United States by the early 1980s. And in the United States, labor policies such as the National Industrial Recovery Act and the National Labor Relations Act were either unwound by President Roosevelt during World War II or declared unconstitutional by the Supreme Court. If these policies had remained in place, the United Kingdom and the United States might be much poorer today than Keynes had predicted.

\section{The "Perils" of Leisure: The Decline of the West?}

According to Keynes, the problem of producing sufficient output was not the central difficulty facing the industrial economies. Rather, it would be dealing with the "problem" of the enormous amount of leisure that would be consumed as societies became sufficiently rich and sated with physical consumption. Keynes's view was likely influenced by the fact that hours worked per adult in the advanced countries were falling during the preceding 50 years. Thus, the central issue for Keynes was creating "solutions" for "the idle hands" of the population as economies grew increasingly wealthy. Keynes forecasts that hours worked might be around 15 hours per week, which would reflect roughly a twothirds decline from the existing workweek length in 1929.

Keynes does not provide any details on how he arrived at this forecast, and this raises the question of what economic theory or quantitative procedures he used to arrive at this number. The decline is much larger than a forecast produced from simply extrapolating the historical decline in hours worked. In particular, hours worked 
per capita declined about 10 percent in the United States between 1889 and 1929, and this same rate of decline between 1929 and 2029 generates a further 23 percent decline, far short of the two-thirds decline predicted by Keynes.

To try to shed light on this forecast and to specifically see if Keynes was making a forecast consistent with modern growth theory, I construct a model economy and simulate it in response to technological change over the century Keynes considered. The model is presented in the Appendix, and here I briefly summarize it. There is a production side of the model, featuring a standard constant returns-to-scale production function that combines labor and capital to produce a single good that is divided between consumption and investment. The production side of the model, featuring labor-augmenting technological progress and capital accumulation, is entirely consistent with Keynes's discussion. As is standard, the capital stock depreciates at a constant rate over time. There is a constant rate of technological progress that leads to increasing wealth over time. Regarding the household side of the model, there is a representative household that values consumption of output and leisure. I make use of the observed decline in hours worked preceding 1929 to quantitatively choose the preference parameters of the model that govern the income elasticities of consumption and leisure. This will tailor the model so that it captures Keynes's expectations that leisure rises as society becomes increasingly wealthy. I will then use the model to deduce the change in hours that would occur in this model economy over the century that Keynes considered.

The solution to the model is characterized by solving a set of nonlinear equations for the endogenous variables in the model - consumption, hours worked, leisure, output, and investment — at each date from 1930 until 2030. The model is solved numerically, since a closed-form solution does not exist for this model.

The model generates the observed decline in hours per adult population between 1889 and 1929, and it generates a 40 percent decline in hours worked between 1929 and 2006, and a 54 percent decline between 1929 and 2029, compared to Keynes's prediction of a 67 percent decline. Thus, Keynes's forecast was fairly close to that predicted by a modern growth model calibrated using the methods developed by real business cycle theorists Kydland and Prescott!

Of course, technological change increases welfare by generating higher leisure and higher consumption in this model. But Keynes held a very different view regarding the value of leisure that he based on his observations of how wealthy women spent their time, and his subjective view of the value of those activities:

[W]ives of the well-to-do classes, unfortunate women ... who have been deprived by their wealth of their traditional tasks ... are quite unable to find anything more amusing.

Keynes extrapolated these opinions more generally, and clarified his view that leisure was indeed a negative consequence of economic growth: "Yet there is no country and no people, I think, who can look forward to the age of leisure and of abundance without a dread."

Keynes takes on the role of a social critic at this juncture. And as a social critic, Keynes stumbles a bit, using neither observation nor theory to guide his reasoning or his conclusions. Keynes presents no evidence or analysis to convince us that wealthy women in 1920s England were indeed "unfortunate," nor does he convince us that their leisure time is unproductive. And his presumption that leisure would continue to rise significantly over time as the world became increasingly wealthy did not occur. Hours worked in the United States and the United Kingdom are in fact higher now than they were 30 years ago, and there seems to be little concern among social scientists studying time allocation that leisure time is not highly valued among households (see Schor 1992).

It is unfair to compare Keynes's social criticism presented in a brief essay to the more detailed analyses of social issues written by others around this time, but it is nevertheless significant that the works of others who addressed similar issues using a blend of economics, sociology, and anthropology are more carefully constructed and informed by observation, and have had more impact. For example, Thorstein Veblen (1899) argued that "status" drove economic activity, and provided support for this argument through socioeconomic data taken from many different cultures over time. Veblen's work has had a long-lasting impact on social science, and even on neoclassical economics (see Cole, Mailath, and Postlewaite 1992). In particular, Veblen's observations and analysis have been regarded as sufficiently interesting as to challenge the neoclassical approach of purely market-based exchange of goods and services.

Cole, Mailath, and Postlewaite were the first to formally incorporate the challenging concepts of "status" and "mores" into neoclassical models and thus study the 
allocation of nonmarket goods in this environment. They interpreted an individual's status as a ranking device that determines their success in the nonmarket sector, and they showed that the existence of a nonmarket sector can endogenously generate a demand in society for relative position. Keynes's best work combined theory and observation in interesting ways, but his discussion of the leisure class did not adequately use either theoretical tools or empirical tools, and his analysis and predictions of this phenomenon were wide off the mark.

\section{Conclusion}

"Economic Possibilities" presents a rare view of Keynes. As Keynes sensibly and clearly describes the foundations and implications of the Solow and Swan models 25 years in advance of their development, his essay provides a glimpse of a gifted economist with enormous potential as a growth theorist. It is indeed intriguing to imagine how the history of growth theory - and economics - could have changed had Keynes pursued growth in greater detail. It is likely that neoclassical growth theory-and perhaps the methods developed by Kydland and Prescott — would have arrived much sooner.

The essay also reveals Keynes to be a judgmental and critical social commentator who uses his economist's pulpit to make a rather puritan-based vision of the future in which he feared that wealth would lead to lives of unproductive leisure and unhappiness. Despite the economic growth that Keynes had predicted, hours worked in advanced countries, such as the United States, remain much higher than he would have predicted. Moreover, declining hours worked in the last 40 years in the European countries are not due to rising wealth, but rather can be accounted for by higher taxation and various labor market restrictions and benefits programs (see Ljungqvist and Sargent 1998; Prescott 2004; Ohanian, Raffo, and Rogerson 2006).

Ironically, Keynes argued that policies that change the incentives to work, consume, and invest would not lead individuals to significantly substitute to nonmarket activities. And since we have not come close to achieving the leisure-filled lives Keynes predicted for the 21st century, the question of how high leisure levels would affect our lives remains unanswered. I do hope that we become sufficiently rich to achieve a society in which individuals choose to consume more leisure, but not because of government policies that reduce the incentives to work and save. 


\section{Appendix: Economic Model}

The economic model that captures Keynes's views about growth and leisure is given by the following constrained maximization problem, in which a representative household maximizes the discounted sum of lifetime utility:

$$
\max \sum_{t=0}^{\infty} \beta^{t}\left\{u\left(c_{t}\right)-v\left(h_{t}\right)\right\}
$$

The maximization problem must obey the set of constraints

$$
\begin{aligned}
& F\left(k_{t}, x_{t} h_{t}\right)=c_{t}+i_{t}, \\
& i_{t}=k_{t+1}-(1-\delta) k_{t}, \\
& x_{t+1}=(1+\gamma) x_{t},
\end{aligned}
$$

where $\beta$ is the rate at which households discount future utility, $c$ is consumption, $h$ is hours worked, $x$ is long-run technological change, $\gamma$ is the growth rate of technology, $i$ is investment, $k$ is capital, $F$ is a constant returns-to-scale technology (which I will assume is Cobb-Douglas with capital share $\theta$ ), and $\delta$ is the depreciation rate.

This model is typically parameterized with balancedgrowth preferences, so that hours worked is constant along the steady-state growth path. The balanced-growth specification requires a unit substitution elasticity between consumption and leisure. For the case of separable utility between consumption and leisure, this requires that preferences are logarithmic in consumption and that $v(h)$ is a convex function. However,
Keynes's view was not balanced growth but rather declining hours worked as wealth increased.

To capture Keynes's view, I assume the following preferences:

$$
u(c)-v(h)=-\left(c_{t}-\bar{c}\right)^{2}-\eta \frac{h_{t}^{1+\psi}}{1+\psi} .
$$

This specification generates higher leisure over time as technology grows and consumption approaches the bliss point, $\bar{c}$. The key parameters in the model that govern the change in hours worked over time are the bliss point value, the curvature parameter $\psi$, the scale parameter $\eta$, and the growth rate of technological progress, $\gamma$. Keynes implicitly predicted a long-run growth rate of technology ranging between 1.4 and 2.1 percent per year, so I will choose a value of $\gamma$ of 1.75 percent per year that is the middle of this range. The parameter $\psi$ governs the labor supply elasticity. I assume that the Frisch elasticity is two, which is consistent with the value of this parameter used in other applications of this model. I choose values for the bliss point $(\bar{c})$ and $\eta$ so that given the rate of technological change, the model generates the observed level of hours worked in the United States in 1889 and in 1929. I choose the year 1889 as the starting date, as it is the earliest year for which Kendrick (1961) constructs aggregate hours worked in the United States. The remaining parameters are $\beta$, the discount factor, and $\delta$, the depreciation rate. These are set to standard values of 0.96 and 0.06 , respectively. 


\section{References}

Cass, David. 1965. Optimum growth in an aggregative model of capital accumulation. Review of Economic Studies 32 (July): 233-40.

Cole, Harold L., George J. Mailath, and Andrew Postlewaite. 1992. Social norms, savings behavior, and growth. Journal of Political Economy 100 (December): 1092-1125.

Cole, Harold L., and Lee E. Ohanian. 2002. The great U.K. depression: A puzzle and possible resolution. Review of Economic Dynamics 5 (January): 19-44.

Cooley, Thomas F., and Lee E. Ohanian. 1997. Postwar British economic growth and the legacy of Keynes. Journal of Political Economy 105 (June): 439-72.

Kendrick, John W. 1961. Productivity trends in the United States. Princeton, N.J.: Princeton University Press.

Keynes, John Maynard. 1930. Economic possibilities for our grandchildren. Reprinted in Essays in persuasion, pp. 358-73. New York: W. W. Norton, 1963.

Koopmans, Tjalling C. 1965. On the concept of optimal economic growth. Pontificiae Academiae Scientiarum Scripta Varia 28: 225-300.

Leamer, Edward E. 2004. Data point: The truth about GDP growth. Harvard Business Review 82 (October): 24.

Ljungqvist, Lars, and Thomas J. Sargent. 1998. The European unemployment dilemma. Journal of Political Economy 106 (June): 514-50.

Lucas, Robert E., Jr. 1988. On the mechanics of economic development. Journal of Monetary Economics 22 (July): 3-42.

Ohanian, Lee E., Andrea Raffo, and Richard Rogerson. 2006. Long-term changes in labor supply and taxes: Evidence from OECD countries, 1956-2004. Research Working Paper RWP 06-16. Federal Reserve Bank of Kansas City.

Pigou, A. C. 1927. Wage policy and unemployment. Economic Journal 37 (September): $355-68$.

Prescott, Edward C. 2004. Why do Americans work so much more than Europeans? Federal Reserve Bank of Minneapolis Quarterly Review 28 (July): 2-13.

Romer, Paul M. 1990. Endogenous technological change. Journal of Political Economy 98 (October): S71-102.

Schor, Juliet B. 1992. The overworked American: The unexpected decline of leisure. New York: Basic Books.

Solow, Robert M. 1956. A contribution to the theory of economic growth. Quarterly Journal of Economics 70 (February): 65-94.

Swan, Trevor W. 1956. Economic growth and capital accumulation. Economic Record 32 (November): 334-61.

Veblen, Thorstein. 1899. The theory of the leisure class. London: Macmillan. 